\title{
Introduction to the special issue: Data Part 2: Experimental Data
}

\author{
${\text { Christian } \text { Kramer }^{2} \cdot \text { John Chodera }}^{3} \cdot$ Terry Stouch $^{1}$
}

Received: 24 September 2015/ Accepted: 28 September 2015/Published online: 1 October 2015

(C) Springer International Publishing Switzerland 2015

This issue is the second in JCAMD's series on Data (see Special Issue: Data Informatics, Journal of ComputerAided Molecular Design, Volume 28, Issue 10, October 2014, Guest Editor: Wendy A. Warr). This issue is devoted to helping us better interpret and properly use the experimental data that is at the core of our research. Too often there is too little understanding of the experiments that give rise to this data, how the data is presented, the inevitable caveats and issues of the experiments, the true error of the results, and the consequential level of confidence that can rightfully be assigned to that data. All too often it seems that there is a "grab the data and run" attitude that does not consider the proper application and use of the data. Not only is that approach uninformed, but it might also mask the success of our calculations.

The articles are not meant to proffer new research, but rather to teach us; to be informative and help us understand the data and its proper interpretation and use. The contributing authors either produce the data, are intimately involved in its interpretation, or both.

We're very grateful to the authors for sharing their time, experience, and insight with us. We also thank the reviewers of these manuscripts for their helpful comments. The authors represent industry, academia, pharmaceutical companies, software companies, and research laboratories from many different countries.

The topics cover assays for measuring physical and biological properties, crystallography, calorimetry, experimental error, data presentation, data curation, essential metadata, data analysis, and data integrity and decision making.

As the editors of this issue, we're proud to present these well-informed works and hope you, the readers, will find them illuminating and helpful.

Terry Stouch

tstouch@gmail.com

1 Journal of Computer-Aided Molecular Design, West Windsor, NJ, USA

2 F. Hoffman-LaRoche, Basel, Switzerland

3 Memorial Sloan-Kettering Cancer Center, New York, NY, USA 